\title{
URGENSI PENDIDIKAN AGAMA DALAM KELUARGA TERHADAP PEMBENTUKAN KEPRIBADIAN ANAK
}

\author{
Jumri Hi. Tahang Basire \\ STAIN Datokarama Palu, Jl. Diponegoro 23 Palu \\ E-mail:jumri_tahang@gmail.com
}

\begin{abstract}
:
Salah satu hal yang mendapatkan perhatian serius dalam ajaran Islam adalah pendidikan terhadap anak. Dua sumber utama ajaran Islam, Alquran dan hadis, banyak memberikan pesan agar para orang tua benar-benar memperhatikan pendidikan agama bagi anak-anak mereka. Dalam konteks ini pulalah keluarga merupakan pilar utama bagi pembentukan kepribadian anak yang perlu dilakukan dengan menanamkan pendidikan agama pada mereka sejak dini. Hal ini tentu saja dimaksudkan agar anak memiliki kepribadian yang tidak mudah dipengaruhi oleh dampak negatif yang terjadi di lingkup kehidupan sosial yang lebih lua.

One of the things that must be seriously paid attention according to Islamic teaching is education of the children. The two sources of Islamic teaching, the Qur'an and the hadith, convey many messages in order that the parents pay attention to religious teaching for their children. Within this context, the family constitutes the main pilar to form the personality of the children which must be conducted by implanting Islamic teaching since the early time. This is intended to encourage the children to possess good personality in order that they will not be easily influenced by a greater social life.
\end{abstract}

Kata Kunci: pendidikan agama, keluarga, kepribadian anak 


\section{PENDAHULUAN}

Dalam perspektif pendidikan, terdapat tiga lembaga utama yang sangat berpengaruh dalam perkembangan kepribadian seorang anak yaitu lingkungan keluarga, lingkungan sekolah dan lingkungan masyarakat, yang selanjutnya dikenal dengan istilah Tripusat Pendidikan. Dalam GBHN (Tap. MPR No. IV/MPR/1978) ditegaskan bahwa "pendidikan berlangsung seumur hidup dan dilaksanakan dalam lingkungan rumah tangga, sekolah dan masyarakat". Oleh karena itu, pendidikan merupakan tanggung jawab bersama antara keluarga, masyarakat dan pemerintah (Darajat, 1992).

Lembaga keluarga merupakan tempat pertama untuk anak menerima pendidikan dan pembinaan. Meskipun diakui bahwa sekolah mengkhususkan diri untuk kegiatan pendidikan, sekolah tidak mulai dari "ruang hampa"(Hery Noer Aly, 2000). Sekolah menerima anak setelah melalui berbagai pengalaman dan sikap serta memperoleh banyak pola tingkah laku dan keterampilan yang diperolehnya dari lembaga keluarga.

Suatu hal yang tidak dapat dipungkiri bahwa pembangunan di segala bidang, manfaatnya semakin hari semakin dirasakan oleh semua kalangan. Revolusi informasi menyebabkan dunia terasa semakin kecil, semakin mengglobal dan sebaliknya privacy seakan tidak ada lagi. Berkat revolusi informasi itu, kini orang telah terbiasa berbicara tentang globalisasi dunia dengan modernitas sebagai ciri utamanya. Dengan teknologi informasi yang semakin canggih, hampir semua yang terjadi di pelosok dunia segera diketahui dan ketergantungan (interdependensi) antar bangsa semakin besar ( Madjid, 2000).

Perkembangan tersebut termasuk di dalamnya perkembangan ilmu pengetahuan di samping mendatangkan kebahagiaan, juga menimbulkan masalah etis dan kebijakan baru bagi umat manusia. Efek samping itu ternyata berdampak sosiologis, psikologis dan bahkan teologis. Lebih dari itu, perubahan yang terjadi juga mempengaruhi nilai-nilai yang selama ini dianut oleh manusia, sehingga terjadilah krisis nilai. Nilai-nilai kemasyarakatan yang 
selama ini dianggap dapat dijadikan sarana penentu dalam berbagai aktivitas, menjadi kehilangan fungsinya (Harahap, 1999).

Untuk menyikapi fenomena global seperti itu, maka penanaman nilai-nilai keagamaan ke dalam jiwa anak secara dini sangat dibutuhkan. Dalam hubungan itu, keluarga pada masa pembangunan (dalam konteks keindonesiaan dikenal dengan era tinggal landas) tetap diharapkan sebagai lembaga sosial yang paling dasar untuk mewujudkan pembangunan kualitas manusia dan lembaga ketahanan untuk mewujudkan manusia-manusia yang berakhlakul karimah (Sulastri, 1993). Pranata keluarga merupakan titik awal keberangkatan sekaligus sebagai modal awal perjalanan hidup mereka (Syamsuddin, 1993).

Mengingat arti penting dan strategisnya makna fungsional keluarga, maka hal itulah yang memotivasi penulis untuk mengangkat masalah ini untuk selanjutnya disuguhkan dalam bentuk makalah.

Berdasarkan latar belakang yang dikemukakan terdahulu, maka yang menjadi permasalahan pokok dalam makalah ini ialah "bagaimana urgensi penerapan pendidikan agama kepada anak dalam keluarga dan peranannya dalam membentuk kepribadian anak". Selanjutnya, permasalahan pokok tersebut dirumuskan untuk menjadi acuan pembahasan adalah: bagaimana urgensi penerapan pendidikan agama terhadap anak dalam keluarga? Bagaimana penerapan pendidikan agama kepada anak dalam keluarga terhadap penanaman nilai-nilai moral keagamaan?

\section{URGENSI PENERAPAN PENDIDIKAN AGAMA TERHADAP ANAK DALAM KELUARGA}

Pendidikan agama merupakan pendidikan dasar yang harus diberikan kepada anak sejak dini ketika masih muda. Hal tersebut mengingat bahwa pribadi anak pada usia kanak-kanak masih muda untuk dibentuk dan anak didik masih banyak berada di bawah pengaruh lingkungan rumah tangga. Mengingat arti strategis lembaga keluarga tersebut, maka pendidikan agama yang merupakan pendidikan dasar itu harus dimulai dari rumah tangga oleh orang tua.

Pendidikan agama dan spiritual termasuk bidang-bidang pendidikan yang harus mendapat perhatian penuh oleh keluarga 
terhadap anak-anaknya. Pendidikan agama dan spiritual ini berarti membangkitkan kekuatan dan kesediaan spiritual yang bersifat naluri yang ada pada kanak-kanak. Demikian pula, memberikan kepada anak bekal pengetahuan agama dan nilai-nilai budaya Islam yang sesuai dengan umurnya sehingga dapat menolongnya kepada pengembangan sikap agama yang betul.

Inti pendidikan agama sesungguhnya adalah penanaman iman kedalam jiwa anak didik, dan untuk pelaksanaan hal itu secara maksimal hanya dapat dilaksanakan dalam rumah tangga. Harun Nasution menyebutkan bahwa pendidikan agama, dalam arti pendidikan dasar dan konsep Islam adalah pendidikan moral. Pendidikan budi pekerti luhur yang berdasarkan agama inilah yang harus dimulai oleh ibu-bapak di lingkungan rumah tangga. Disinilah harus dimulai pembinaan kebiasaan-kebiasaan yang baik dalam diri anak didik. Lingkungan rumah tanggalah yang dapat membina pendidikan ini, karena anak yang berusia muda dan kecil itu lebih banyak berada di lingkungan rumah tangga daripada di luar (Nasution, 1995).

Tugas lingkungan rumah dalam hal pendidikan moral itu penting sekali, bukan hanya karena usia kecil dan muda anak didik serta besarnya pengaruh rumah tangga, tetapi karena pendidikan moral dalam sistem pendidikan kita pada umumnya belum mendapatkan tempat yang sewajarnya. Pendidikan formal di Indonesia masih lebih banyak mengambil bentuk pengisian otak anak didik dalam pengetahuan-pengetahuan yang diperlukan untuk masa depannya, sehingga penanaman nilai-nilai moral belum menjadi skala prioritas. Oleh sebab itu, tugas ini lebih banyak dibebankan pada keluarga atau rumah tangga. Jika rumah tangga tidak menjalankan tugas tersebut sebagaimana mestinya, maka moral dalam masyarakat kita akan menghadapi krisis.

Dari segi kegunaan, pendidikan agama dalam rumah tangga berfungsi sebagai berikut: pertama, penanaman nilai dalam arti pandangan hidup yang kelak mewarnai perkembangan jasmani dan akalnya, kedua, penanaman sikap yang kelak menjadi basis dalam menghargai guru dan pengetahuan di sekolah (Tafsir, 1994).

Bagaimanapun sederhananya pendidikan agama yang diberikan di rumah, itu akan berguna bagi anak dalam memberi nilai pada teori-teori pengetahuan yang kelak akan diterimanya di 
sekolah. Inilah tujuan atau kegunaan pertama pendidikan agama dalam rumah tangga.

Oleh karena itu, peranan pendidikan (khususnya pendidikan agama) memainkan peranan pokok yang sepatutnya dijalankan oleh setiap keluarga terhadap anggota-anggotanya. Lembaga-lembaga lain dalam masyarakat, seperti lembaga politik, ekonomi dan lainlain, tidak dapat memegang dan menggantikan peranan ini. Lembaga-lembaga lain mungkin dapat membantu keluarga dalam tindakan pendidikan, akan tetapi tidak berarti dapat menggantikannya, kecuali dalam keadaan-keadaan luar biasa (Langgulung, 1995).

Barangkali ada orang yang sering berbicara tentang pendidikan sementara pandangannya tertuju secara khusus kepada sekolah. Pendidikan lebih luas dari sekedar sekolah. Memang sekolah merupakan suatu lembaga yang mengkhususkan diri untuk kegiatan pendidikan, namun tidak dipungkiri bahwa sekolah menerima anak setelah anak ini melalui berbagai pengalaman dan memperoleh banyak pola tingkah laku dan keterampilan dalam rumah tangga.

Dalam kehidupan masyarakat primitif, keluarga menjalankan proses pengembangan sosial anak dengan memperkenalkan berbagai keterampilan, kebiasaan dan nilai-nilai moral yang berlaku dalam kehidupan komunitas. Karena kehidupan masyarakat primitif masih sederhana, baik dalam anasir-anasir maupun isinya, maka pola-pola pendidikannya pun masih sangat sederhana. Sejalan dengan perkembangan sejarah dan kompleknya kehidupan, terjadi perubahan besar terhadap masyarakat. Implikasinya, anakanak mengalami kesulitan untuk belajar dengan sekedar meniru. Demikian pula, orang tua sudah mengalami kesulitan untuk tetap tinggal bercengkrama bersama anak-anaknya sepanjang hari. Dari situ muncul kebutuhan akan suatu lembaga khusus yang membantu keluarga dalam mendidik anak-anak dan memelihara kelangsungan hidup komunitas (Aly, 2000).

Demikianlah, keluarga pernah dan masih tetap merupakan tempat pendidikan pertama, tempat anak berinteraksi dan menerima kehidupan emosional. Individu dewasa ini menghadapi arus informasi dan budaya modern yang mesti disikapi. Kesalahan utama yang dilakukan budaya modern yang berpijak pada budaya 
barat adalah lahirnya pandangan bahwa segala yang bersumber dari barat diserap dan dianggap sebagai ciri kemodernan (Ashmed, 1993). Akibatnya, penyerapan secara membabi buta terhadap cara pandang seperti itu menyebabkan generasi-generasi muda (remaja) terjerumus ke dalam berbagai bentuk penyimpangan dan kenakalan yang tidak dapat ditolerir secara agamis.

Persoalan kenakalan remaja yang sering menjadi buah bibir dan bahan diskusi berbagai kalangan merupakan salah satu tema yang merupakan implikasi dari salah kaprah terhadap makna modernitas. Berkumpulnya remaja-remaja yang menyebabkan terganggunya orang-orang yang ada di sekelilingnya, tindakantindakan seperti minum minuman keras, menelan obat-obat terlarang, pemuasan nafsu seksual, dan bentuk-bentuk kejahatan lainnya, sebagaian besar merupakan akibat dari kesalahan pemaknaan tersebut. Di samping itu, egoisme pribadi yang mengakibatkan pelecehan terhadap hak-hak orang lain menandai dunia yang semakin maju.

Bekal pendidikan agama yang diperoleh anak dari lingkungan keluarga akan memberinya kemampuan untuk mengambil haluan di tengah-tengah kemajuan yang demikian pesat. Keluarga muslim merupakan keluarga-keluarga yang mempunyai tanggung jawab yang sangat besar dalam mendidik generasi-generasinya untuk mampu terhindar dari berbagai bentuk tindakan yang menyimpang. Oleh sebab itu, perbaikan pola pendidikan anak dalam keluarga merupakan sebuah keharusan dan membutuhkan perhatian yang serius.

Suatu kenyataan yang dapat dipastikan bahwa masa remaja adalah masa yang penuh dengan kegoncangan, di samping itu disadari pula bahwa remaja mempunyai potensi yang sangat besar. Oleh karena itu, remaja sangat memerlukan pembinaan. Agamalah yang dapat membantu mereka dalam mengatasi dorongan-dorongan dan keinginan-keinginan yang belum pernah mereka kenal sebelumnya yang seringkali bertentangan dengan nilai-nilai agama yang dianut oleh para orang tua atau lingkungan tempat mereka hidup. Ajaran agama Islam berintikan keyakinan (aqidah), ibadah, syariah dan akhlak yang sangat membantu dalam mengatasi kehidupan remaja yang serba kompleks (Getteng, 1997). 
Pembentukan kepribadian anak sangat erat kaitannya dengan pembinaan iman dan akhlak. Secara umum para pakar kejiwaan berpendapat bahwa kepribadian merupakan suatu mekanisme yang mengendalikan dan mengarahkan sikap dan perilaku seseorang. Kepribadian terbentuk melalui semua pengalaman dan nilai-nilai yang diserap dalam pertumbuhannya, terutama pada tahun-tahun pertama dari umurnya. Apabila nilai-nilai agama banyak masuk ke dalam pembentukan kepribadian seseorang, tingkah laku orang tersebut akan diarahkan dan dikendalikan oleh nilai-nilai agama. Di sinilah letak pentingnya pengalaman dan pendidikan agama pada masa-masa pertumbuhan dan perkembangan seseorang. Oleh sebab itu, keterlibatan orang tua (baca: keluarga) dalam penanaman nilainilai dasar keagamaan bagi anak semakin diperlukan (Darajat, 1993).

Dalam kaitannya dengan pendidikan anak dalam keluarga, dapat memberikan implikasi-implikasi sebagai berikut:

\section{Anak Memiliki Pengetahuan Dasar-dasar Keagamaan}

Kenyataan membuktikan bahwa anak-anak yang semasa kecilnya terbiasa dengan kehidupan keagamaan dalam keluarga, akan memberikan pengaruh positif terhadap perkembangan kepribadian anak pada fase-fase selanjutnya. Oleh karena itu, sejak dini anak seharusnya dibiasakan dalam praktek-praktek ibadah dalam rumah tangga seperti ikut shalat jamaah bersama dengan orang tua atau ikut serta ke mesjid untuk menjalankan ibadah, mendengarkan khutbah atau ceramah-ceramah keagamaan dan kegiatan religius lainnya. Hal ini sangat penting, sebab anak yang tidak terbiasa dalam keluarganya dengan pengetahuan dan praktekpraktek keagamaan maka setelah dewasa mereka tidak memiliki perhatian terhadap kehidupan keagamaan (Hasbullah, 1999).

Pengetahuan agama dan spiritual termasuk bidang-bidang pendidikan yang harus mendapat perhatian penuh oleh keluarga terhadap anak-anaknya. Pengetahuan agama sangat berarti dalam membangkitkan kekuatan dan kesediaan spritual yang bersifat naluri yang ada pada anak melalui bimbingan agama dan pengalaman ajaran-ajaran agama dan pengamalan ajaran-ajaran agama yang disesuaikan dengan tingkatan usianya, sehingga dapat menolong untuk mendapatkan dasar pengetahuan agama yang 
berimplikasi pada lahirnya kesadaran bagi anak tersebut untuk menjalankan ajaran agama secara baik dan benar (Langgulung, 1995).

Dirumah, ayah dan ibu mengajarkan dan menanamkan dasardasar keagamaan kepada anak-anaknya, termasuk di dalamnya dasar-dasar kehidupan bernegara, berprilaku yang baik dan hubungan-hubungan sosial lainnya. Dengan demikian, sejak dini anak-anak dapat merasakan betapa pentingnya nilai-nilai keagamaan dalam pembentukan kepribadian. Latihan-latihan keagamaan hendaknya dilakukan sedemikian rupa sehingga menumbuhkan perasaan aman dan memiliki rasa iman dan takwa kepada sang pencipta.

Apabila latihan-latihan keagamaan diterapkan pada waktu anak masih kecil dalam keluarga dengan cara yang kaku atau tidak benar, maka ketika menginjak usia dewasa nanti akan cenderung kurang peduli terhadap agama atau kurang merasakan pentingnya agama bagi dirinya. Sebaliknya, semakin banyak si anak mendapatkan latihan-latihan keagamaan sewaktu kecil, maka pada saat ia dewasa akan semakin marasakan kebutuhannya kepada agama (Darajat, 1996)

Menurut Umar Hasyim, mempelajari agama di rumah adalah pendidikan yang penting dan akan terasa amat terkesan dan mendalam bagi penghayatan agama oleh keluarga, terutama dalam pembentukan kepribadian agamis anak (Hasyim, 1985).

Keluarga menjadi tempat berlangsungnya sosialisasi yang berfungsi dalam pembentukan kepribadian sebagai makhluk individu, makhluk sosial, makhluk susila dan makhluk keagamaan. Jika anak mengalami atau selalu menyaksikan praktek keagamaan yang baik, teratur dan disiplin dalam rumah tangganya, maka anak akan senang meniru dan menjadikan hal itu sebagai adat kebiasan dalam hidupnya, sehingga akan dapat membentuknya sebagai makhluk yang taat beragama. Dengan demikian, agama tidak hanya dipelajari dan diketahui saja, tetapi juga dihayati dan diamalkan dengan konsisten (Barnadib, 1983).

Keluarga merupakan masyarakat alamiah yang dalam pergaulan dengan anggotanya memiliki ciri spesifik. Disini pendidikan berlangsung dengan sendirinya sesuai dengan tatanan pergaulan yang berlaku di dalamnya. Dasar-dasar pengalaman 
dapat diberikan melalui rasa kasih sayang dan penuh kecintaan, kebutuhan akan kewibawaan dan nilai-nilai kepatuhan. Justru karena pergaulan yang demikian itu berlangsung dalam hubungan yang bersifat pribadi dan wajar, maka penghayatan terhadapnya mempunyai arti yang amat penting (Darajat, 1992).

\section{Anak Memiliki Pengetahuan Dasar Akhlak}

Keluarga merupakan penanaman utama dasar-dasar akhlak bagi anak, yang biasanya bercermin dalam sikap dan prilaku orang tua sebagai teladan yang dapat dicontoh anak. Dalam hubungan ini, Ki Hajar Dewantara menyatakan bahwa rasa cinta, rasa bersatu dan lain-lain perasaan dan keadaan jiwa yang pada umumnya sangat berfaedah untuk berlangsungnya pendidikan, teristimewa pendidikan budi pekerti, terdapat dalam kehidupan keluarga dengan sifat yang kuat dan murni, sehingga pusat-pusat pendidikan lainnya tidak dapat menyamainya (Suwarno, 1985).

Tampak jelas bahwa tingkah laku, cara berbuat dan berbicara akan ditiru oleh anak. Dengan teladan ini, melahirkan gejala identifikasi positif, yakni penyamaan diri dengan orang yang ditirunya. Perlu disadari bahwa sebagai tugas utama dari keluarga bagi pendidikan anak ialah peletak dasar bagi pendidikan anak ialah peletak dasar bagi pendidikan akhlak dan pandangan hidup keagamaan. Sifat dan tabiat anak sebagian besar diambil dari kedua orang tuanya dan dari anggota keluarga lainnya (Ahmad, 1986).

Pendidikan agama sangat terkait dengan pendidikan akhlak. Tidak berlebihan jika dikatakan bahwa pendidikan akhlak dalam pengertian islam adalah bagian yang tidak dapat dipisahkan dari pendidikan agama. Hal tersebut karena agama selalu menjadi parameter, sehingga yang baik adalah yang dianggap baik oleh agama dan yang buruk adalah yang dianggap buruk oleh agama. Oleh sebab itu, tujuan tertinggi pendidikan islam adalah mendidik jiwa dan akhlak (Arifin, 1996).

Keluarga adalah sekolah tempat putra putri belajar. Dari sana mereka mempelajari sifat-sifat mulia, sifat kesetiaan, kasih sayang, gairah (kecemburuan positif) dan sebagainya. Dari kehidupan keluarga, seorang ayah atau suami memupuk sifat keberanian dan keuletan dalam upaya membela sanak keluarga dan membahagiakan mereka pada saat hidup dan setelah kematiannya 
(Shihab, 1997). Keluarga adalah unit terkecil yang menjadi pendukung dan pembangkit lahirnya bangsa dan masyarakat.

Dari segi pendidikan, keluarga memegang peranan yang sangat penting untuk melanjutkan dan mengembangkan sosial budaya yang telah diajarkan kepada anak. Dianggap bahwa kejadian shari-hari dalam kehidupan keluarga, anak-anak harus mempelajari kebenaran dan peraturan-peraturan yang ada, menghormati hak dan perasan orang lain, menghindari pergaulan yang kurang baik dan lain sebagainya (Partowisastro, 1983). Pada setiap anak, sebagian besar tingkah lakunya diberi corak oleh tradisi kebudayaan serta kepercayaan keluarga. Hanya saja hal ini belum tentu dapat dipastikan, karena adanya gejala bosan terhadap tradisi lama.

Dasar-dasar kelakuan anak tertanam sejak dini dalam keluarga, sikap hidup serta kebiasaan. Bagaimana pun adanya pengaruh luar, pengaruh keluarga tetap terkesan pada anak karena di dalam keluargalah anak itu hidup dan menghabiskan waktunya. Lingkungan keluarga harus merasa bertanggungjawab atas kelakuan, pembentukan watak, kesehatan jasmani dan rohani (mental) (Bernadib, 1995).

Jadi penerapan pendidikan keluarga, khususnya dalam pendidikan, akhlak harus dibina dari kecil dengan pembiasaanpembiasaan dan contoh teladan dari keluarga terutama kedua orang tua. Dengan demikian anak akan memiliki pengetahuan tentang dasar-dasar akhlak.

\section{Anak Memiliki Pengetahuan Dasar Sosial}

Anak adalah generasi penerus yang di masa depannya akan menjadi anggota masyarakat secara penuh dan mandiri. Oleh karena itu seorang anak sejak kecil harus sudah mulai belajar bermasyarakat, agar nantinya dia dapat tumbuh dan berkembang menjadi manusia yang dapat menjalankan fungsi-fungsi sosialnya. Orang tua harus menyadari bahwa dirinya merupakan lapisan mikro dari masyarakat, sehingga sejak awal orang tua sudah menyiapkan anaknya untuk mengadakan hubungan sosial yang di dalamnya akan terjadi proses saling mempengaruhi satu sama lain.

Keluarga merupakan lingkungan sosial yang pertama dikenalkan kepada anak, atau dapat dikatakan bahwa seorang anak 
itu mengenal hubungan sosial pertama-tama dalam lingkungan keluarga. Adanya interaksi anggota keluarga yang satu dengan keluarga yang lain menyebabkan seorang anak menyadari akan dirinya bahwa ia berfungsi sebagai individu dan juga sebagai makhluk sosial. Sebagai individu, ia harus memenuhi segala kebutuhan hidupnya demi untuk kelangsungan hidupnya di dunia ini. Sedangkan sebagai makhluk sosial, ia menyesuaikan diri dengan kehidupan bersama yaitu saling tolong-menolong dan mempelajari adat-istiadat yang berlaku dalam masyarakat. Dengan demikian, perkembangan seorang anak dalam keluarga sangat ditentukan oleh kondisi keluarga dan pengalaman-pengalaman yang dimiliki oleh orang tuanya sehingga, di dalam kehidupan bermasyarakat akan kita jumpai bahwa perkembangan anak yang satu dengan yang lain akan berbeda-beda (Ahmadi, 1997).

Kehidupan keluarga dibangun atas hubungan-hubungan sosial yang diatasnya terletak tanggung jawab penting terhadap orang perorang dan terhadap masyarakat umum. Mengingat pentingnya kehidupan keluarga dalam masyarakat sehari-hari, maka para pemikir dan filosof zaman klasik telah merencanakan dan menggambarkan segala sesuatu yang dapat menunjang keberhasilan dan kelangsungan keluarga itu. Perhatian para pemikir tentang pangaturan kehidupan masyarakat sangat memprioritaskan kepada pengenalan akan pentingnya keluarga karena ia merupakan inti dan unsur pertama dalam masyarakat (Fahmi, 1983).

Lingkungan sosial yang pertama bagi anak ialah rumah. Di sanalah terdapat hubungan yang pertama antara anak dengan orangorang yang mengurusnya. Hubungan diwujudkan dengan air muka, gerak-gerik dan suara. Karena hubungan ini, anak belajar memahami gerak-gerik dan air muka orang lain. Hal ini penting sekali artinya untuk perkembangan selanjutnya. Air muka dan gerak-gerik itu memegang peranan penting dalam hubungan sosial. Kemudian alat hubungan kedua yang penting yang mula-mula dipelajari di rumah adalah bahasa. Dengan bahasa, anak itu mendapat hubungan yang lebih baik dengan orang-orang yang serumah dengannya. Sebaliknya anak dapat pula berkata yang tidak senonoh atau mencaci maki dengan menggunakan bahasa pula.

Hal yang penting diketahui bahwa lingkungan keluarga itu akan membawa perkembangan perasaan sosial yang pertama 
misalnya, perasaan simpati yaitu suatu usaha untuk menyesuaikan diri dengan perasaan orang lain. Anak-anak itu merasa simpati kepada orang dewasa dan juga kepada orang yang mengurus mereka. Dari rasa simpati itu tumbuhlah kelak pada anak-anak itu rasa cinta terhadap orang tua dan kakak-kakaknya. Demikian pula, perasaan simpati itu menjadi dasar untuk perasaan cinta terhadap sesama manusia. Di samping itu, lingkungan keluarga dapat memberi suatu tanda peradaban yang tertentu kepada sekalian anggotanya. Dari caranya bercakap-cakap, berpakaian, bergaul dengan orang lain, dapat kita kenal pertama kali dalam lingkungan keluarga. Lingkungan keluarga sangat mempengaruhi perasaan sosial anak selanjutnya.

Sebagai akibat dari pengalaman sosialnya, anak yang sedang berkembang menerima sejumlah besar ilmu tentang dunia dan bagaimana dunia beroperasi. Ia juga akan mengembangkan nilainilai tentang bagaimana ia harus berinteraksi dengan dunia itu. Pendidikan informal adalah semua pengajaran dan pelajaran yang dilakukan atau dialami manusia sepanjang hidupnya (D.F Swiff, 1989).

Dengan demikian, terlihat betapa besar tanggung jawab orang tua terhadap anak. Bagi seorang anak, keluarga merupakan persekutuan hidup pada lingkungan keluarga tempat di mana ia menjadi pribadi atau diri sendiri. Selain itu, keluarga juga merupakan wadah bagi anak dalam konteks proses belajarnya untuk mengembangkan dan membentuk diri dan fungsi sosialnya. Di samping itu, keluarga merupakan tempat belajar bagi anak dalam segala sikap untuk berbakti kepada Tuhan sebagai perwujudan hidup yang tertinggi.

\section{PENUTUP}

Penerapan pendidikan agama terhadap anak dalam keluarga secara dini memiliki tingkat urgenitas yang sangat besar. Hal tersebut mengingat bahwa peranan yang dimainkan oleh lembaga pendidikan formal tidak mampu menggantikan posisi lembaga keluarga dalam penanaman nilai-nilai moral keagamaan. Fenomena tersebut menempatkan pendidikan dalam lembaga keluarga menempati posisi strategis. Dalam hal ini, lembaga keluarga di 
samping menanamkan modal dasar bagi anak, juga melengkapi kekurangan-kekurangan sistem pendidikan formal,

Penerapan pendidikan agama terhadap anak sangat berpengaruh terhadap pembentukan sikap dan tingkah laku anak. Pemberian modal-modal keagamaan dalam keluarga, secara garis besarnya dapat melahirkan implikasi-implikasi sebagai berikut: (a) anak memiliki pengetahuan dasar-dasar keagamaan, (b) anak memiliki pengetahuan dasar akhlak, (c) anak memiliki pengetahuan dasar sosial. Pengetahuan-pengetahuan dasar tersebut memiliki arti penting untuk pencapaian tujuan asasi dari pendidikan Islam, yaitu penanaman iman dan akhlaqul karimah.

Mengingat besarnya peranan yang dimainkan keluarga dalam penanaman nilai-nilai moral terhadap anak maka perlu dilakukan kerjasama yang baik antara pihak lembaga pendidikan formal dengan lembaga keluarga dalam membina para peserta didik. Terjadinya miskomunikasi antara pihak pengelola lembaga pendidikan formal akan melahirkan model pendidikan yang tidak terpadu. Fenomena seperti itu dengan sendirinya akan berkonsekuensi terhadap lahirnya sikap saling menyalahkan antara pihak lembaga pendidikan formal dengan pihak orang tua peserta didik. Sebaliknya, terjadi komunikasi yang produktif antara kedua lembaga tersebut akan melahirkan rumusan-rumusan dan pola-pola pembinaan terpadu, sehingga kekurangan-kekurangan sistem kurikulum pendidikan formal akan diisi oleh orang tua peserta didik dengan pembinaan-pembinaan yang saling mendukung keberhasilan peserta didik,

Mengingat besarnya peranan orang tua dalam penanaman nilai-nilai moral dan keagamaan anak maka pendidikan tidak hanya penting diterapkan kepada anak, tetapi juga terhadap orang tua. Minimnya pengetahuan keagamaan orang tua juga sangat mempengaruhi kualitas pembinaannya terhadap anak. Oleh sebab itu, dipandang perlu untuk merumuskan pola-pola pembinaan orang tua secara terencana oleh pihak pemerintah bekerjasama dengan pihak sekolah.

\section{DAFTAR PUSTAKA}


Al-Abrasyiy, Muhammad 'Atiyyah. 1996. Roh Al-Islam, diterjemahkan oleh Syamsuddin Asyrofi et al. Dengan judul Beberapa Pemikiran Pendidikan Islam. Cet. I.Yogyakarta: Titian Ilahi Press.

Ahmad, Khursid. 1986. Family Life in Islam, diterjemahkan oleh Soetomo dengan judul Keluarga Muslim. Cet. I. Bandung: Risalah.

Ahmadi, Abu dan Nur Uhbiyati. 1991 Ilmu Pendidikan. Cet. I. Jakarta: Rineka Cipta.

Ahmadi, Abu dan Nur Uhbiyati. 1991. Sosiologi Pendidikan. Cet. I. Jakarta: Rineka Cipta.

Ahmed, Akbar S. 1993. Post Modernisme and Islam; Predicement and Promise, terjemahan Bahasa Indonesia dengan judul Posmodernisme; Bahaya dan Harapan Bagi Islam. Bandung: Mizan.

Aly, Hery Noer dan H. Munzier, S. 2000. Watak Pendidikan Islam. Cet. I. Jakarta: Friska Agung Insani.

Arifin, M. 1996. Ilmu Pendidikan Islam: Suatu Tinjauan Teoritis dan Praktis Berdasarkan Pendekatan Interdisipliner. Cet. IV. Jakarta: Bumi Aksara.

Barnadib, Imam. 1983. Pemikiran Tentang Pendidikan Baru. Yogyakarta: Andi Offset.

Barnadib, Imam. 1995. Pengantar Ilmu Pendidikan Sistematis. Cet. XV. Yogyakarta: Andi Offset.

Daradjat, Zakiah. 1996. Ilmu Jiwa Agama (Cetakan Kelima belas). Jakarta: Bulan Bintang.

Daradjat, Zakiah.1992. Ilmu Pendidikan Islam (Cetakan Kedua). Jakarta: Bumi Aksara.

Daradjat, Zakiah. 1993. Tinjauan Anak Dalam Keluarga: Tinjauan Psikologi Agama, dalam Jalaluddin Rakhmat dan Mukhtar Gandaatmaja, (peny.), Keluarga Muslim dalam Masyarakat Modern. Cet. I. Bandung: Remadja Rosdakarya.

Departemen Agama RI. 1989. Al-Qur'an dan Terjemahnya. Semarang: Toha Putra.

Fahmi, Mustafa. 1983. Penyesuaian Diri: Lapangan Implementasi dari Penyesuaian Diri (Cetakan Pertama). Jakarta: Bulan Bintang. 
Getteng, H. Abd. Rahman. 1997. Pendidikan Islam dalam Pembangunan. Ujungpandang: Yayasan al-Ahkam.

Harahap, H. Syahrin. 1999. Islam; Konsep dan Imlementasi Pemberdayaan. Cet. I. Yogyakarta: Tiara Wacana Yogya.

Hasbullah. 1999. Dasar-dasar Ilmu Pendidikan. Cet. I. Jakarta: Raja Grafindo Persada.

Hasyim, Umar. 1985. Cara Mendidik Anak dalam Islam, Seri II. Surabaya: Bina Ilmu.

Ibnu Musthafa. 1997. Keluarga Islam Menyongsong Abad ke-21. Cet. II. Bandung: Mizan.

Izzat, Hibbah Rauf. 1997. Al-Mar'ah Wa al-'Amal al Siysiy: Ru'yah Islamiah. Diterjemahkan oleh Baharuddin Fannani dengan judul Wanita dan Politik; Pandangan Islam. Cet. I. Bandung: Remadja Rosdakarya.

Langgulung, Hasan. 1995. Manusia dan Pendidikan: Suatu Analisa Psikologi dan Pendidikan. (Cetakan Ketiga). Jakarta: Al-Husna Zikra, 1995.

Madjid, Nurcholish. 2000. Islam Doktrin dan Peradaban; Sebuah Telaah Kritis tentang Masalah Keimanan, Kemanusiaan dan Kemodernan. (Cetakan Keempat). Jakarta: Paramadina.

Majelis Luhur Persatuan Taman Siswa. 2000. Karya Ki Hajar Dewantara, Bagian I. Yogyakarta: t.p.

Muhaimin dan Abd. Mujib. 1993. Pemikiran Pendidikan Islam; Kajian Filosofis Kerangka Dasar Operasionalnya (Cetakan Pertama). Bandung: Trigenda Karya.

Nasution, Harun. 1995. Islam Rasional Gagasan dan Pemikiran. Jakarta: Mizan.

Partowisastro, Koestoer. 1983. Dinamika dalam Psikologi Anak (Jilid I Cetakan Pertama). Jakarta: Erlangga.

Rivai, Melly Sri Sulastri. 1993. Suatu Tinjauan Historis Prospektif tentang Perkembangan Kehidupan dan Pendidikan Keluarga, dalam Jalaluddin Rakhmat dan Mukhtar Gandaatmaja (peny.), Keluarga Muslim dalam Masyarakat Modern. (Cetakan Pertama). Bandung: Remadja Rosdakarya. 
Shihab, M. Quraish. 1997. Membumikan al-Qur'an (Cetakan Kedua). Bandung: Mizan.

Soejono, Ag. 1979. Aliran Baru Dalam Pendidikan (Cetakan Pertama). Bandung: CV. Ilmu.

Suwarno. 1985. Pengantar Umum Pendidikan. Jakarta: Aksara Baru.

Swiff, D.F. 1989. the Sociology of Education: Introductory Analitycal Perpectives, diterjemahkan oleh Panuti Sudjiman dan Greta Librata dengan judul Sosiologi Pendidikan: Penrspektif Pendahuluan yang Analitis. Jakarta: Bharata Niaga Media.

Syamsuddin, M., TB. Abin. 1993. Kata Sambutan, dalam Jalaluddin Rahmat dan Myhtar Gandaatmaja (peny.), Keluarga Muslim dalam Masyarakat Modern. (Cetakan Pertama). Bandung: Remadja Rosdakarya.

Tafsir, Ahmad. 1994. Ilmu Pendidikan dalam Perspektif Islam. Bandung: Remadja Rosdakarya.

Tafsir, Ahmad. 1992. Ilmu Pendidikan dalam Perspektif Islam (Cetakan Pertama). Bandung: Remadja Rosdakarya.

Wahyoctomo. 1997. Perguruan Tinggi Pesantren; Pendidikan Alternatif Masa Depan (Cetakan Pertama). Jakarta: Gema Insani Press 